\title{
POTENSI DAN DAYA DUKUNG LESTARI TEGAKAN AREN DI DESA LANNE
}

\author{
Potential and Sustainable Support of Aren Stands in Lanne Village
}

\author{
Dewi Indasary ${ }^{1 \varpi}$, Nurul Hikmah Melilani ${ }^{1}$, Muhammad Ramdhan Rachmat², Suhasman ${ }^{3}$ \\ ${ }^{1}$ Mahasiswa fakultas Pertanian, Universitas Hasanuddin, Jl. Perintis Kemerdekaan Km.10 Tamalanrea Makassar \\ 2Mahasiswa Fakultas Kehutanan, Universitas Hasanuddin, Jl. Perintis Kemerdekaan Km.10 Tamalanrea Makassar \\ ${ }^{3}$ Staf Pengajar Fakultas Kehutanan, Universitas Hasanuddin, Jl. Perintis Kemerdekaan Km.10 Tamalanrea Makassar \\ ${ }^{\triangle}$ corresponding author: dewiindasary@icloud.com
}

\begin{abstract}
Palm trees have high economic potential because almost all parties can provide financial benefits. But of all palm products, the palm sap that comes from the male flower arm as an ingredient for the production of brown sugar is the greatest economic value. However, there are some people who prefer to cut palm trees for cultural purposes instead of properly handling them to be used as brown sugar. This research aims to analyze the carrying capacity and potential of palm trees in Lanne Village. The location of this investigation was carried out in Lanne Village, Tondong Tallasa District, Pangkajene and Kepulauan Regency, South Sulawesi Province. The location of the sugar palm administrators is in two villages, namely, Manjalling and Mariololo. The research method used is a qualitative research method that uses inventory, observation and interview techniques. The results obtained are that for now the people of Lanne do not comply with the capacity of sustainable cargo. The presence of sugar palm is now relatively minor. Therefore, to restore the glory of the sugar palm sugar population must be added
\end{abstract}

Key words: interview, inventory, potential, sugar palm, sustainable carrying capacity

\section{A. PENDAHULUAN}

Hutan mempunyai berbagai jenis manfaat yang dapat dinikmati oleh semua orang baik yang berwujud nyata (tangible benefits) maupun yang tak berwujud nyata (intangible benefits) (Hani, 2009). Pada umumnya, orang hanya memanfaatkan hutan dari kayunya saja, potensi hasil hutan bukan kayu (HHBK) seringkali tidak. Padahal HHBK juga dapat membantu pendapatan masyarakat dalam jumlah yang besar (Makarennu, dkk., 2015)

Hasil Hutan Bukan Kayu (HHBK) merupakan bagian dari ekosistem hutan yang memiliki peran terhadap alam maupun terhadap manusia. Menurut Salaka, dkk. (2012) peran hasil hutan bukan kayu tidak hanya dari segi ekologis, tetapi juga pada aspek ekonomis dan sosial budaya. HHBK juga dapat diperoleh secara gratis dan memiliki nilai ekonomi yang sangat tinggi bila dikelola dengan baik. Maka dapat disimpulkan bahwa HHBK sendiri dapat memenuhi kebetuhan masyarakat seperti keperluan pangan, papan dan ritual lainnya. Salah satu HHBK yang memiliki nilai ekonomi tinggi dan merupakan salah satu sumber pencaharian masyarakat pedesaan adalah Arenga pinnata atau yang dikenal dengan enau atau aren (Suhesti \& Hadinoto, 2015).

Tanaman aren (Arenga pinnata MERR) adalah tanaman perkebunan yang dapat menjadi solusi dalam masyrakat yang kekurangan pangan dan mudah beradaptasi baik pada dataran rendah hingga $1400 \mathrm{~m}$ di atas permukaan laut (Effendi, 2009). Saat ini tanaman aren belum diusahakan dalam skala besar melainkan hanya diusahakan oleh para petani. Hal ini disebabkan karena pengelolaan tanaman belum menerapkan teknik budidaya yang baik sehingga produktivitas tanaman rendah. Saat ini nira aren dari hasil penyadapan bunga jantan hanya dikelola sebagai gula aren maupun minuman ringan, cuka dan alkohol (Akuba, 2004). Selain itu tanaman aren juga dapat menghasilkan produk makanan seperti kolang kaling dari buah betina yang sudah masak dan tepung aren untuk bahan makanan dalam bentuk kue, roti dan biskuit juga berasal dari pengolahan bagian empelur batang tanaman (Alam dan Baco, 2004).

Menurut Rumokoi (2004) dari hasil pengolahan data Ditjenbun tahun 2003 menghasilkan bahwa estimasi perkembangan areal tanaman aren di beberapa provinsi di Indonesia telah ditanami seluas 60.482 ha dengan produksi gula aren mencapai 30.376 ton/tahun. Hal ini disebabah karena tanaman aren dapat berdapatasi dengan berbagai kondisi kondisi lahan dan dapat diperoleh secara gratis. Tanaman ini memberikan produksi nira yang layak diusahakan dengan input rendah dan sangat cocok untuk tujuan konservasi air dan tanah. Di samping itu, tanaman aren menghasilkan biomas di atas tanah dan dalam tanah yang sangat besar sehingga berperan penting dalam siklus $\mathrm{CO}_{2}$ (Syakir \& Effendi, 
2010). Tanaman aren atau enau adalah salah satu keluarga palma yang memiliki potensi nilai ekonomi yang tinggi dan dapat tumbuh subur di wilayah tropis seperti Indonesia (Abdul \& Hery, 2015). Tanaman aren diambil niranya oleh masyarakat dan diolah menjadi gula aren untuk sebagai salah satu sumber pendapatan.

Tanaman aren kini hanya dapat dijumpai di lerenglereng perbukitan yang ada di desa tersebut. Salah satu faktor yang turut mempercepat penurunan populasi tanaman aren adalah budaya masyarakat yang senantiasa menebang minimal satu tanaman aren setiap kali ada kegiatan pesta adat untuk dijadikan sebagai salah satu menu wajib pesta. Eksistensi tanaman aren baik sebagai pohon ikonik maupun sebagai sumber pendapatan masyarakat serta bagian penting dari pesta budaya mengalami ancaman serius.

Padahal, potensi tanaman aren untuk menjadi salah satu penopang utama ekonomi masyarakat setempat sangat tinggi. Tanaman aren bukan hanya dapat dikembangkan sebagai penghasil nira aren untuk bahan baku gula aren. Tapi lebih dari itu, apabila tanaman aren ini dapat dikembangkan, boleh jadi suatu saat dapat menjadi pohon ikonik bagi pengembangan desa wisata. Potensi ini sangat memungkinkan direalisasikan, mengingat landscape wilayah tersebut yang indah, cuaca sejuk, serta jaraknya yang hanya sekitar $85 \mathrm{~km}$ dari ibu kota Provinsi Sulawesi Selatan yaitu Makassar.

Namun, masyarakat masih sangat minim minatnya untuk mengelola tanaman aren untuk dijadikan gula aren. Beberapa masyarakat lebih memilih menebang tanaman aren dan masih belum menyadari potensi yang dapat dihasilkan dari tanaman aren. Maka dari itu tujuan dari penilitian ini untuk menganalisis potensi dan daya dukung tanaman aren di Desa Lanne, Kecamatan Tondong Tallasa, Kabupaten Pangkajene dan Kepulauan, Provinsi Sulawesi Selatan.

\section{B. METODE PENELITIAN}

Penelitian ini terbagi atas dua kegiatan. Kegiatan pertama adalah mengetahui potensi tanaman aren di Desa Lanne. Kegiatan kedua adalah mengetahui daya dukung tanaman aren di Desa Lanne. Data yang dikumpulkan dengan teknik inventarisasi dengan menggunakan intensitas sampling yaitu 4,8\% dari 169 ha dan teknik wawancara ditujukan kepada kelompok tani. Penilitian ini dilaksanakan di Dusun Lanne, Kecamatan Tondong Tallasa, Kabupaten Pangkajene dan Kepulauan, Provinsi Sulawesi Selatan.

\section{Prosedur Penelitian}

Penelitian ini diawali dengan tahapan persiapan yang meliputi penetapan daerah sasaran yaitu di Dusun Manjalling dan Dusun Mariololo sebagai tempat tumbuh aren dan tempat pengelola aren. Penetapan daerah sasaran tersebut didasarkan pada observasi awal yang telah dilakukan sebelumnya. Pertama, kami menentukan informan kunci yaitu kepala desa untuk memberikan petunjuk siapa informan selanjutnya yang berkompeten memberikan data. Tahapan selanjutnya menganalisis tingkat daya dukung lestari tanaman aren dengan menggunakan teknik inventarisasi tanaman aren serta persepsi masyarakat dalam pemanfaatan tanaman aren dengan melakukan wawancara menggunkan kuesioner.

\section{Teknik Pengumpulan Data}

\section{Observasi}

Teknik observasi dilakukan yaitu untuk mendapatkan gambaran awal lokasi penelitian yaitu di Desa Lanne. Observasi ini dilakukan secara lebih detail. Objek yang diamati terutama difokuskan pada wilayah yang menurut keterangan informan merupakan sentra pertumbuhan tanaman aren.

\section{Inventarisasi Tegakan Aren}

Inventarisasi tegakan aren dilakukan untuk mengumpulkan data potensi tegakan aren dilakukan dengan kombinasi informasi dari hasil interpretasi citra landsat, hasil observasi lapangan dengan didampingi oleh kepala dusun setempat serta inventarisasi tegakan. Kegiatan ini diawali dengan observasi lalu mengambil data-data koordinat untuk dikorelasikan dengan peta citra landsat. Selanjutnya dilakukan delineasi lokasi tegakan aren dengan memanfaatkan data hasil koordinat yang diperoleh serta hasil observasi bersama kepala dusun. Setelah lokasi tumbuhan aren diketahui, selanjutnya dihitung luasnya kemudian ditetapkan jumlah sampel pengamatan. Dalam penelitian ini pengamatan dilakukan dengan metode line sampling (Ardiansyah, 2016).

Line sampling adalah pengambilan contoh dalam satu garis (jalur) yang telah ditetapkan sebelumnya. Dalam penelitian ini, digunakan 8 jalur dengan dua titik awal yang berbeda.Masing-masing jalur tersebut memiliki lebar jalur $20 \mathrm{~m}$ dengan panjang bervariasi antara $436 \mathrm{~m}$ sampai dengan $582 \mathrm{~m}$. Total panjang jalur sampling adalah 8.088 $\mathrm{m}$ atau setara dengan 8 ha. Dengan demikian intensitas sampling yang digunakan adalah $4,8 \%$ dari total luas kawasan aren yaitu 169 ha. Pada masing-masing jalur tersebut dilakukan pencatatan terhadap setiap tanaman aren yang ditemukan. Dalam pencatatannya dikelompokkan menjadi dua kategori yaitu aren dewasa dan aren permudaan.

\section{Wawancara}

Teknik ketiga yang kami gunakan yaitu teknik wawancara. Wawancara yang digunakan yaitu dengan cara terstruktur dan mendalam. Pertama, dengan melakukan wawancara terstruktur yang tertuju ke petani aren dengan menggunakan kuesioner. Kedua, dengan wawancara mendalam yang melibatkan kepala desa, kepala dusun dan masyrakat yang dianggap paham tentang tanaman aren. Wawancara mendalam ini 
dilakukan secara terbuka tanpa menggunakan kuesioner. Dalam proses wawancara ini, pewawancara menanyakan kepada informan secara detail dan akurat mengenai informasi pemanfaatan tanaman aren dan persepsi tentang keberadaan tanaman aren.

\section{Teknik Analisis Data}

Hasil inventarisasi tegakan diolah untuk mendapatkan data jumlah tanaman aren dewasa dan jumlah tanaman permudaan per ha untuk setiap jalur dengan menggunakan persamaan (1).

Jumlah pohon per ha pada jalur ke-i $=\frac{P_{i}}{L_{i}}$

Keterangan : $P_{i}=$ Jumlah pohon pada jalur ke-i; $L_{i}=$ Luas jalur ke-i (dalam ha)

Data ini diolah lebih lanjut sehingga didapatkan potensi tegakan aren, baik aren dewasa maupun aren permudaan untuk keseluruhan wilayah tegakan aren sebesar $169 \mathrm{Ha}$.

Data hasil wawancara ditabulasi untuk mendapatkan potret kecenderungan masing-masing responden untuk setiap pertanyaan yang diajukan, baik terkait pemanfaatan, persepsi keberadaan aren, maupun kontribusi ekonominya.Catatan hasil wawancara mendalam dicatat dan dianalisis untuk mendapatkan aspek-aspek penting dari masing-masing informan. Kedua data ini dianalisis secara deskriptif untuk mendapatkan gambaran komprehensif terkait berbagai aspek terkait aren.

\section{HASIL DAN PEMBAHASAN}

Hasil lapangan di DesaLanne, Kecamatan Tondong Tallasa, Kabupaten Pangkajene dan Kepulauan, Provinsi
Sulawesi Selatan terdiri atas 4 dusun yaitu Dusun Manjalling, Dusun Mariololo, Dusun Lanne, dan Dusun Tagari. Namun, dari hasil observasi menunjukkan bahwa hanya tesisa Dusun Manjalling yang masih mengelola aren. Hal ini dikarenakan pada masyarakat Dusun Manjalling, Dusun Mariololo, dan Dusun Tagari memiliki kebiasaan menebang pohon aren untuk kepentingan pesta adat.

Untuk mengidentifikasi lokasi tumbuh tanaman aren, maka dilakukan pengambilan titik koordinat di lapangan dimana tanaman aren ditemukan dan dijelaskan oleh masyarakat sebagai daerah terluar tanaman aren. Informasi ini dipadukan dengan interpretasi citra landsat untuk memetakkan areal tanaman aren. Berdasarkan hasil deliniasi, luas tanaman aren di Dusun Manjalling adalah 169 ha dari perpaduan hasil observasi dan interpretasi citra.

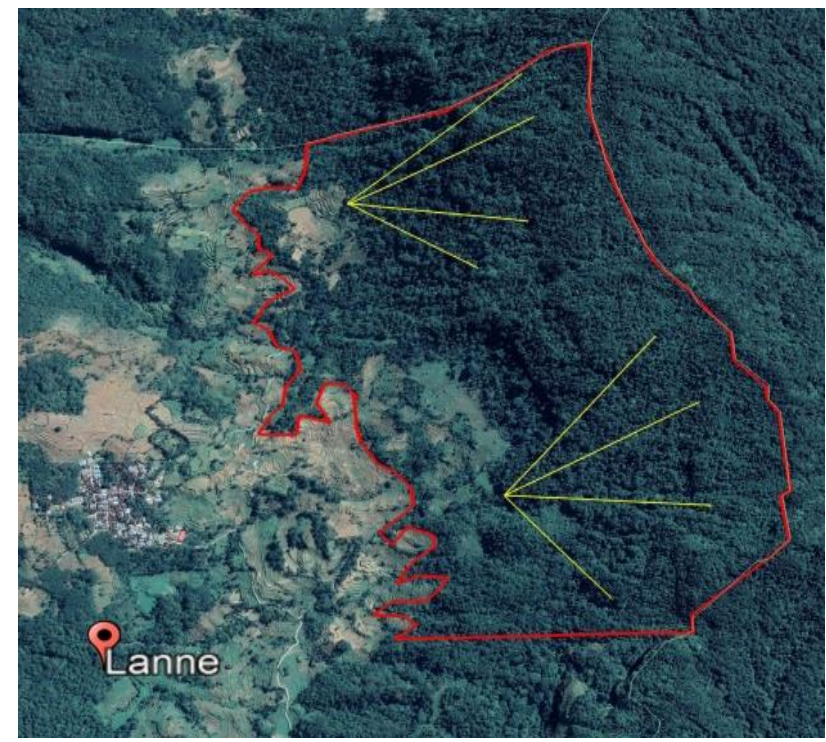

Gambar 1. Deliniasi aren di Dusun Manjalling

Tabel 1. Hasil Inventarisasi Aren di Dusun Manjalling

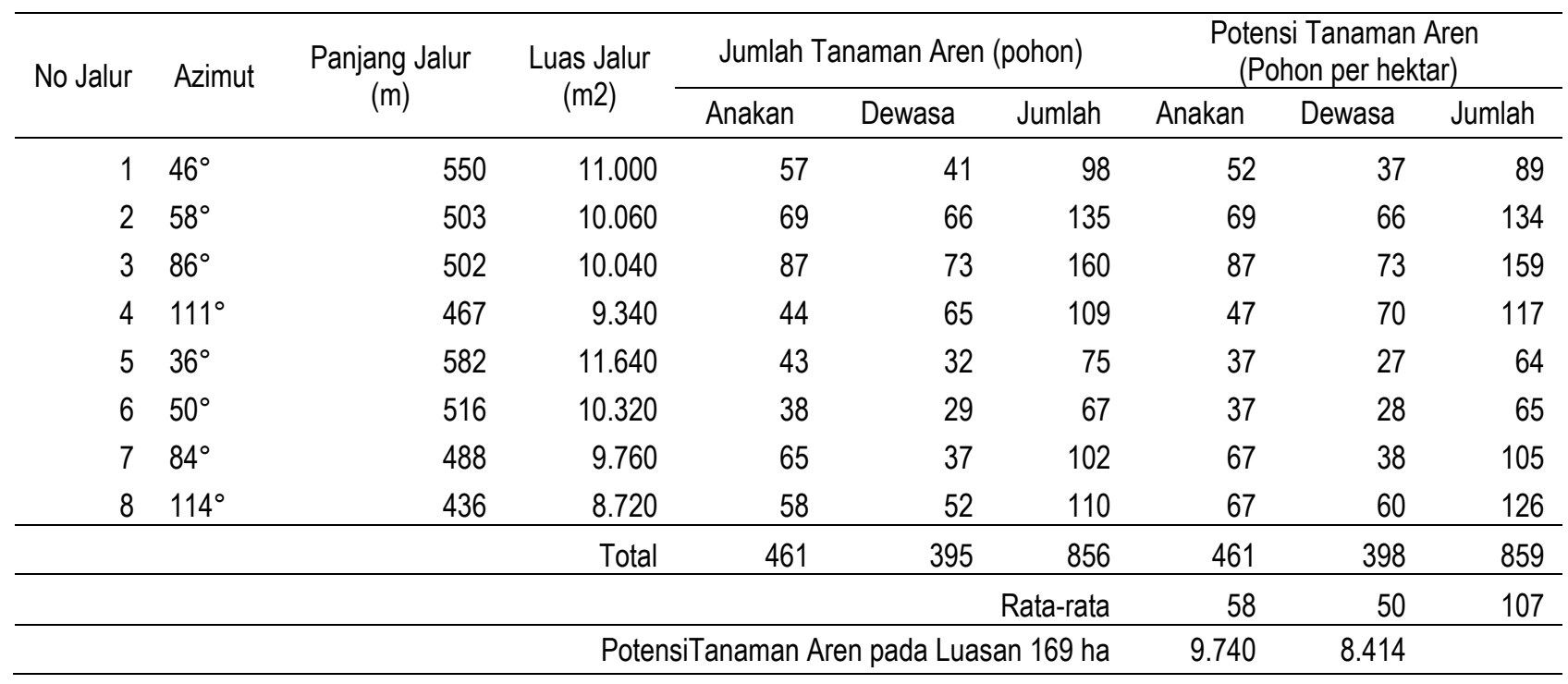




\section{Tingkat Daya Dukung Lestari Tanaman Aren}

\section{Potensi Tanaman Aren}

Hasil wawancara mendalam dengan Kepala Desa Lanne mengatakan bahwa dalam setahun jumlah pesta adat yang dilaksanakan mencapai 115 kali yang terdiri atas, pesta pernikahan, aqiqah, sunatan, serta pindah rumah baru. Hasil wawancara yang dilakukan dengan 9 responden yang berada di Dusun Mariololo mengatakan bahwa jumlah tanaman aren yang digunakan setiap ada pesta adat rata-rata 4 pohon. Sedangkan hasil wawancara dengan 16 responden yang berada di Dusun Manjalling juga mengatakan bahwa jumlah tanaman aren yang digunakan setiap ada pesta adat rata-rata 4 pohon. Jadi jumlah total tanaman aren yang ditebang untuk keperluan pesta adat di Desa Lanne adalah rata-rata 460 pohon per tahun.

Dengan memperhatikan kedua data di atas dimana potensi permudaan sebesar 9.740 pohon. Umur ideal tanaman aren yang digunakan untuk konsumsi budaya yaitu 5 tahun. Maka potensi pertahun permudaan aren yang tersedia saat ini yaitu sebesar 1.948 pohon. Hasil penelitian ini menunjukan potensi aren dewasa adalah 8.414 pohon. Hasil wawancara menunjukkan bahwa daur produktif aren menghasilkan nira yaitu sejak berumur 7 tahun hingga 9 tahun. Apabila diasumsikan aren dewasa yang ada saat ini terdistribusi secara merata pada tiap rentang umur maka setiap tahun akan ada 2.104 pohon yang akan berhenti berproduksi dan harus digantikan oleh permudaan aren dan potensi permudaan aren hanya ada 1.948 pohon tiap tahunnya , maka untuk saat ini tidak ada tanaman aren yang dapat ditebang untuk dijadikan menu pesta adat, karena jika ada maka dipastikan tanaman aren nantinya akan punah. Perlu diketahui bahwa ada 8.414 pohon aren dewasa yang dapat menghasilkan nira. Namun masyarakat yang mengelola aren ada 25 orang dan setiap orang hanya menangani dua pohon aren setiap harinya jadi hanya ada sekitar 50 aren yang ditangani padahal potensinya ada 8.414 pohon. Eksistensi aren terancam akibat kebiasaan masyarakat yang menebang pohon untuk dijadikan menu pesta adat. Disisi lain aren yang ada tidak dikelola dengan baik. Kurangnya perhatian masyarakat terhadap tanaman aren.

Berdasarkan perhitungan rata-rata yang ditebang selama ini ada 460 pohon dalam setahun, sementara untuk permudaannya tidak ada pohon yang tersisa untuk ditebang sebagai menu pesta adat, maka untuk saat ini tidak memenuhi daya dukung lestari. Hasil wawancara dengan informan-informan kunci mengatakan dibanding dulu, keberadaan aren sekarang relatif lebih sedikit. Sehingga untuk mengembalikan kejayaan aren semestinya populasi aren harus ditambah.

\section{Pemanfaatan Aren}

Pohon aren yang ada di Desa Lanne sudah ada sejak dahulu karena pada dasarnya pohon aren tersebut tumbuh secara alami di Desa Lanne. Hasil wawancara bersama informan - informan kunci mengatakan bahwa populasi aren saat ini lebih sedikit dibandingkan dulu. Eksistensi aren tetap terjaga karena bagi masyarakat sekitar aren bukan hanya sekedar sebagai sumber penghasilan tetapi juga sebagai salah satu menu wajib pesta adat. Masnyarakat Desa Lanne memanfaatkan nira aren untuk dijadikan gula. Gula aren merupakan salah satu sumber penghasilan bagi masyarakat Desa Lanne. Disisi lain, bagian pucuk dari tanaman aren dimanfaatkan sebagai sayuran yang disajikan pada saat pesta adat. Bagian pucuk tanaman ini dapat diperoleh dengan cara menebang tanaman aren. Kedua fungsi tanaman aren, baik sebail sebagai penghasil nira maupun sebagai bahan baku dalam pesta adat memiliki kedudukan yang sama pentingnya. Hasil wawancara menjelaskan $60 \%$ masyarakat menjawab aren dapat menambah pendapatan dan $40 \%$ menjawab sangat penting untuk dijadikan sebagai menu wajib pada saat pesta adat.

Salah satu kebiasaan masyarakat yang mengancam eksistensi aren adalah penggunaan aren untuk kebutuhan pesta - pesta adat. Mereka menggunakan aren sebagai salah satu menu pesta adat sudah menjadi kebiasaan sejak dahulu. Terbukti dari hasil wawancara masyarakat di Dusun Mariololo cenderung menggunakan aren untuk kebutuhan pesta adat dalam jumlah yang jauh lebih besar dan kenyataannya sekarang pohon aren sudah sangat sulit dijumpai di dusun tersebut sementara di Dusun Manjalling pohon aren masih dapat dijumpai karena kebiasaan masyarakat menggunakan tanaman aren untuk kebutuhan pesta adat dalam jumlah sedikit.

Penggunaan tanaman aren untuk pesta adat sebagai salah satu bahan makanan dengan pemanfaatan nira untuk dijadikan gula merah sebagai sumber penghasilan saling bertolak belakang. Penggunaan untuk pesta adat menuntut tanaman aren harus ditebang, disisi lain pemanfaatan niranya menuntut tanaman aren harus dijaga hingga dewasa. Namun demikian, ketika masyarakat ditanya mana yang lebih penting dari keduanya mereka menjawab bahwa kedua-duanya penting. Ini bermakna bahwa fungsi ekonomi dan fungsi budaya memiliki kedudukan yang sama pentingnya sehingga dalam pengelolaannya harus diseimbangkan antara fungsi ekonomi dan fungsi budaya. Berdasarkan hasil wawancara, masyarakat sangat berharap eksistensi tanaman aren tetap dijaga keberadaannya kalau perlu ditingkatkan populasinya karena mereka memiliki ketergantungan yang tinggi terhadap tanaman aren baik untuk kepentingan budaya maupun ekonomi.

\section{E. KESIMPULAN}

Berdasarkan perhitungan rata-rata tanaman aren yang ditebang untuk kepentingan pesta adat dalam setahunnya sebanyak 460 pohon sementara untuk permudaannya tidak ada pohon yang tersisa untuk ditebang sebagai menu pesta adat, maka untuk saat ini 
tidak memenuhi daya dukung lestari. Hasil wawancara dengan informan - informan kunci mengatakan dibanding dulu, keberadaan aren sekarang relatif lebih sedikit. Sehingga untuk mengembalikan kejayaan aren semestinya populasi aren harus ditambah.

Penggunaan untuk pesta adat menuntut tanaman aren harus ditebang, disisi lain pemanfaatan niranya menuntut pohon aren harus dijaga hingga dewasa. Ini bermakna bahwa fungsi ekonomi dan fungsi budaya memiliki kedudukan yang sama pentingnya sehingga dalam pengelolaannya harus diseimbangkan antara fungsi ekonomi dan fungsi budaya.

\section{UCAPAN TERIMA KASIH}

Peneliti meyakini bahwa peneliti tidak akan pernah bisa menyelesaikan penelitian ini tanpa bantuan dan bimbingan dari orang-orang disekitarnya yang luar biasa. Oleh sebab itu di sini peneliti hendak menyampaikan ucapan terima kasih kepada pihak yang sudah membantu yaitu kepada Belmawa Kemenristekdikti yang sudah mendukung penuh penelitian ini, Civitas Akademika Unhas yang sudah banyak membantu, dan kepada seluruh pemerinta Kabupaten Pangkep dan masyarakat Desa Lanne. Serta seluruh pihak yang telah membantu yang tentu tidak dapat saya sampaikan seluruhnya. Terima kasih banyak.

\section{DAFTAR PUSTAKA}

Akuba, R. . (2004). Profil Aren: Pengembangan Tanaman Aren. Prosiding Seminar Nasional Aren, 1-9. Tondano: Balai Penelitian Tanaman Kelapa dan Palma Lain.

Alam, S., \& Baco, D. (2004). Peluang Pengem-bangan dan Pemanfaatan Tanaman Aren di Sulawesi Selatan. Prosiding Seminar Nasional Aren., 15-21. Tondano: Balai Penelitian Tanaman Kelapa dan Palma Lain.

Ardiansyah, T. (2016). Inventarisasi Hutan: Teknik Sampling dengan Unit Contoh Berbeda Ukuran.

Effendi, D. S. (2009). Aren, Sumber Energi Alternatif. Warta Penelitian Dan Pengembangan Pertanian, 31(2), 1-3.

Fatah, A., \& Sutejo, H. (2015). Tinjauan Keragaan Tanaman Aren (Arrenga piñata Merr) di Kabupaten Kutai Barat. Jurnal Agrifor, XIV(1).

Hani, A. (2009). Pengembangan Tanaman Penghasil Hasil Hutan Bukan Kayu Melalui Perbanyakan Vegetatif. Tekno Hutan Tanaman, 2(2), 83-92.

Makkarennu, Rum, M. F., \& Ridwan. (2018). Analisis Pendapatan Usaha Gula Aren pada Masyarakat yang Tinggal di Dalam dan Sekitar Hutan. Jurnal Perennial, 14(2), 61-65.

Rumokoi, M. M. . (2004). Aren, Kelapa dan Lontar Sebagai Alternatif Pemenuhan Kebutuhan Gula Nasional. Prosiding Seminar Nasional Aren. Tondano: Balai Penelitian Tanaman Kelapa dan Palma Lain.

Salaka, F. J., Nugroho, B., \& Nurrochmat, D. R. (2012). Strategi Kebijakan Pemasaran Hasil Hutan Bukan Kayu di Kabupaten Seram Bagian Barat, Maluku. E-Journal Analisis Kebijakan Kehutanan, 9(1), 30-65.

Suhesti, E., \& Hadinoto, H. (2015). Hasil Hutan Bukan Kayu Madu Salang di Kabupaten Kampar (Studi Kasus: Kecamatan Kampar Kiri Tengah). Wahana Forestra: Jurnal Kehutanan, 10(2), 16-26. 